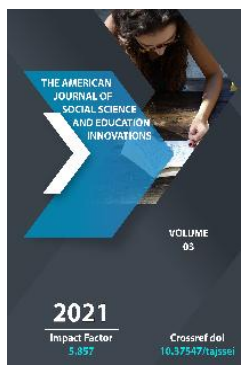

\title{
The Phenomenon Of Pedagogical Support Is The Basis Of A Humanistically Oriented Educational Process
}

\section{Yusupov Ikrom}

Senior Teacher, Karshi Institute Of Engineering Economics, Karshi City, Uzbekistan

Journal Website:

http://theamericanjour

nals.com/index.php/taj

ssei

Copyright: Original content from this work may be used under the terms of the creative commons attributes 4.0 licence.

\section{ABSTRACT}

The article takes up some aspects of the phenomenon of pedagogical support of students while educational process. Present phenomenon is described in the light of humanistic paradigm. The article calls attention to different authors's view on pedagogical support and criteria of this phenomenon.

\section{KEYWORDS}

Pedagogical support; educational process; humanistic; subject-to-subject relationships; collaboration.

\section{INTRODUCTION}

It is very important from the perspective of to pedagogical support of the individual, since the humanistic paradigm that scientists turn pedagogical support is one of the structure- 
forming elements of the humanistic approach, the semantic nerve of humane pedagogy. Thus, pedagogical support of the student's personality is a functional component of the humanistic education system.

The problem of pedagogical support was covered in the works of O.S. Gazman, T.V. Anokhina, A.V. Mudrik, V.G. Kovalenko, N.N. Mikhailova, N.P. Krylova, T.V. Frolova, S. M. Yusfin, N. Yu. Shustova and other scientists who formulated the essential features of this phenomenon, such as: cooperation as the leading type of interaction, providing the counter movement of the personal meanings of the teacher and the student (OS Gazman); student amateur performance, (N. N. Mikhailova, S. M. Yusfin); objective and subjective problems of pedagogical support (N. B. Krylova); individual assistance and support for individualization of development (A. V. Mudrik).

Adherents of pedagogical support, defining its essence, characterize this phenomenon as a complex, multifaceted, multidimensional pedagogical phenomenon. Pedagogical support is considered as:

- A special pedagogical category, since the student "in

- In conditions of support and care, he begins to manifest himself not just in active and positive behavior - he enters into higher layers of interaction and cooperation with an adult "[2];

- "A system of means that provide assistance to students in independent individual choice - moral, professional, existential self-determination, as well as assistance in self-realization in educational, communicative and professional activities" [1];

- A special type of complex, high-tech professional pedagogical (but psycho- intensive) activity, which requires different relations between adults and children, where cooperation and interaction between a teacher and a student becomes a reference point, an equal and mutually beneficial exchange of personal meanings and experience;

- A complex education, which is subjectively perceived as an experience of a positively colored feeling of self-confidence, one's own need, arising from empathy and receiving help (L.A. Petrovskaya).

Thus, the innovative value of pedagogical support lies in the fact that it is a system of methods of truly free and humane education, completely and completely focused on the development and self-development of individuality, on the student's selfdetermination and self-realization, his individual educational, professional and life processes.

The idea of supporting a child in one form or another and in connection with various tasks was present in many education systems, in some form proclaiming the priority of humanistic values:

- Foreign: J. Locke, J.-J. Rousseau, F. Frebel, F. Disterweg, J. Dewey, M. Montessori, S. Frene, J. Korczak, A. Neill, J. Hall;

- Domestic: L. N. Tolstoy, K. N. Ventzel, S. T. Shatskiy, A. S. Makarenko, V. A. Sukhomlinsky, S. L. Soloveichik, O. S. Gazman;

- Modern domestic: Sh. A. Amonashvili, A. A. Galitskikh, I. D. Demakova, V. A. Karakovsky, S. D. Polyakov, M. P. Shchetinina, etc.

It should be noted that in humanistic educational systems, the idea of support was implemented in different forms. The importance lies in the fact that support was 
present as a natural background of trusting interaction between teachers and students and was declared as a special, innovative, sphere of pedagogical activity aimed at selfdetermination and self-determination of the student.

It should be noted that one of the most important principles reflecting the content of support is the development of subject-subject relations between participants in the educational process. The content of these relations is the basis of humanistic education, thanks to them there is an introduction of students to the norms of human society, the development of socially valuable patterns of behavior, the "cultivation" of the subjective qualities of a person. The basis of such a relationship can be called the cooperation of teacher and students. Its essence lies in the teacher's ability to connect to the goals and objectives of the students. Connection to goals and objectives is possible through the specific situation of the student's life, as well as through connection to his subjective experience. In the system of interaction "on an equal footing", the centering on the personality of the child is realized, communication is built according to the type of double dominance, which provides psychological security for the growing person, and also reflects the humanistic orientation of the interaction of the subjects of the educational process [4].

Taking into account all of the above, we should talk about the basic conditions that E.V. Ignatovich simultaneously characterizes as criteria for the methodological foundations of the process of pedagogical support and protection of the personality of students in the context of the philosophy of humanism. Such conditions can be considered: the attitude to a person as to an intrinsic value, as to a being that has absorbed the significant potentialities of the human race; student's desire for self-organization, self-realization, dedication as a means and a way of expressing one's "I" in a multicultural educational space; support for the active, creative nature of the student's life, the need for positive freedom, openness, the ability to freely manifest themselves in a multicultural society; the likelihood of self-design, forecasting the future based on personification and personality identification in a multicultural environment [3].

Summing up, we can conclude that pedagogical support of a student in the modern space of an educational institution is aimed at creating a humane, culturally consistent learning environment that promotes the establishment of the principles of universal morality; ensuring the spiritual community of generations; the formation of civic consciousness, human dignity; selfdetermination of students; the formation of subjectivity; self-actualization of the selflearning process; instilling the ability to express their thoughts, take initiative, make decisions, build their own life strategy.

\section{REFERENCES}

1. Anokhina TV Pedagogical support as a reality of modern education // New values of education. - 1996. - No. 6. - P. 71-90.

2. Gazman OS From authoritarian education to pedagogy of freedom // New values of education: a thesaurus for teachers and school psychologists. - M., 1995. - P. 16-46.

3. Ignatovich EV Pedagogical conditions for the formation of a moral and psychological climate in an educational institution: dis. ... Cand. ped. sciences. Petrozavodsk, 2005.

4. Sizova OR Preparation of future teachers for pedagogical support of moral selfdetermination of schoolchildren and adolescents: dis. ... Cand. ped. sciences. Petrozavodsk, 2004. 